\title{
Developing technology acceptance model for e-service purposes
}

\author{
Mohamed Bakry Mohamed ${ }^{\mathrm{a}^{*}}$ and Tarig Mohamed Ahmed ${ }^{\mathrm{b}}$
}

${ }^{a}$ Assistant. Prof. Dept. Management, College of Business Administration, Prince Sattam Bin Abdalaziz University, Saudi Arabia ${ }^{b}$ Associate Prof. Dept. Computer, FMS, University of Khartoum, Khartoum, Sudan

CH R O N I C L E

Article history:

Received: February 2, 2020

Received in revised format:

March 112020

Accepted: March 11, 2020

Available online:

March 14, 2020

Keywords:

e-services

Technology Acceptance Model

UTAUT

\section{A B S T R A C T}

Nowadays, universities are investing resources in optimizing e-services to enhance delivery of services to their employees. Most of them provide their services electronically to improve the performance of their organizations. These services are categorized into two classes: academic and nonacademic. This paper focuses on nonacademic class, which is important to measure what factors influence on the e-services. This manuscript aims to develop an acceptance technology model to figure out what the factors motivate nonacademic staff at the universities continuously use the eservices. The proposed model is based on technology acceptance model (TAM) and its extension. It consists of multiple constructs that reflect the opinions of nonacademic staff in e-services. The model was implemented by using questionnaire, 308 employees responded from Prince Sattam Bin Abdalaziz University to this questionnaire by giving their opinions. The feedback was analyzed deeply. The results indicate that technology fit was positively related to user's perceived satisfaction by using E-Services when the level of significant was one percent. Also, performance expectancy was positively related to user's perceived satisfaction. The research finding could be used by university ICT departments to enhance the quality of e-services.

(C) 2020 by the authors; licensee Growing Science, Canada

\section{Introduction}

Universities are investing resources for optimizing e-services to enhance delivery of services to their employees (Naicker \& Singh, 2019). E-services play very important role on efficiently. Universities around world are looking for full automation to enhance overall administrative works performance (Venkatesh et al., 2003). In addition, e-services aim to deal with different sources of data at universities and make them available to university employees. With an increasing number of universities, the e-service quality is a vital concern toward satisfying the employees who are one of the stakeholders (Ali, 2019; Dishaw \& Strong, 1999). Prince Sattam Bin Abdulaziz University established in 2009 is a public higher education institution located in city of Al-Kharj (population 376325 inhabitants). Officially accredited/recognized by the Ministry of Education, Saudi Arabia, Prince Sattam Bin Abdulaziz University (PSAU) is a coeducational higher education institution. Prince Sattam Bin Abdulaziz University (PSAU) offers courses and programs leading to officially recognized higher education degrees such as bachelor degrees in several areas of study. PSAU also provides several academic and nonacademic facilities and services to employees including a library, as well as administrative services. Prince Sattam Bin Abdulaziz University (PSAU) offers E-services portal to provide services to employees such as financial, human resource, purchasing and others administrative services. This paper investigates the impacts of factors persuades nonacademic staff to use e-services in administration. The model is used to help the ICT improve the quality and flexibility of the e-services. Also, this research identifies the impact of using e-service as technology on the performance of the employees. The technology acceptance model (TAM) and its extension 
were used to develop a research model. The model consists of multiple constructs that reflect the opinions of government employees in E-Service. In addition, the model is validated and tested.

\section{Theoretical background}

\subsection{E-Services}

An employee's acceptance and confidence are keys for further development of any new technology (Taherdoost, 2018). Saudi Arabia has given high priorities as important goal to computerize all services to enhance quality of administration processes in national institutes of higher education and through the e-service, this goal can be achieved. The government allocated a huge resource to build strong infrastructure at universities for e-services. This is mainly due to the valuable advantage of a university environment as reported by several researches and practical experiences (Persico et al., 2014). This research aims to identify the employees' adoption factors using e-services (university portal) in Prince Sattam Bin Abdulaziz University. The research model was developed based on the use of Unified Theory of Acceptance and Use of Technology (UTAUT) and DeLone and McLean IS success model (Venkatesh et al., 2003). In addition, some factors proposed by the researches have been added to the model. UTAUT has four core factors of intention and usage measurements, and four moderators of key relationships. It helps to know how the new technologies such as e-services will succeed. The model also used Technology Fit to measure the acceptability of using the e-services by employees (Lin \& Wang, 2012). To collect employees' opinion about current e-services that are providing by PSAU, a questioner survey was designed. The questioner was tested by using the reliability and validity for its different constructs.

\subsection{The Unified Theory of Acceptance and Use}

Venkatesh et al. (2003) developed UTAUT as extension of TAM to measure perceived usefulness and usage intention. UTAUT related to information system adoption research. By using UTAUT, user intention of using information system and subsequent usage behavior could be measured. UAUT uses usage intention behavior constructs for measuring performance expectancy, effort expectancy, social influence, and Self-Efficacy (not from UTAUT). All these constructs were used in this research to the employees' technology acceptance and use the e-service as information systems. To measure how the e-services provide benefits and increases the activities performance at the university environment, the performance expectancy was used. The effort expectancy was used to measure the degree of free effort and how much mental effort is needed when employees are using e-services. To measure the impact of those around the employee on the use of e-services such as employees or friends or family, social influence was used. The Self-Efficacy construct was used to measure the degree of difficulties and self-trust of using e-services.

\subsection{The IS success model}

Information system (IS) success model (Delone \& McLean, 2003) was proposed by Delone and McLean, which is an information systems theory. IS success model describes the relationship between information, system and service quality on one hand and the usage intention and user satisfaction on the other hand. The research model uses IS success to measure how the knowledge and information quality intention the employee to use e-services. It also measures the relationship between the knowledge and information quality and perceived benefit of using e-services (Wang et al., 2007).

\subsection{The task-technology fit model}

Goodhue and Thompson (1995) developed Task-technology fit model (TTF). It is related to two items: Task Characteristics and Technology characteristics. The model specifies the appropriateness of the implemented tasks by using technologies. Also, it measures the impacts of the user performance. TTF was used to measure how e-services is good as mediation to deliver the services and facilitate the communication between employees and other entities in the university environment.

\section{Research model and hypotheses}

\subsection{Task-technology fit}

Several research studies have reported that Task-technology fit has positive influence on user's acceptance of E-Service Systems (Lin \& Wang, 2012)

$\mathrm{H}_{1}$ : Task-technology fit is positively related to user's Perceived Satisfaction with using E- Service systems.

$\mathrm{H}_{2}$ : Self Efficacy is positively related to user's Perceived Benefits of using E- Service systems. 


\subsection{The unified theory of acceptance and use of technology}

Venkatesh et al. (2003) reported the performance expectancy can predict users' intention to accept the use technology. In addition, Chiu and Wang (2008) found that effort expectancy positively influences user's continuance intention to use EServices systems. Therefore, we hypothesized the following:

$\mathrm{H}_{3}$ : Performance expectancy is positively related to user's Perceived Satisfaction with using E- Services systems.

$\mathrm{H}_{4}$ : Performance expectancy is positively related to user's Perceived Benefits of using E- Services systems.

$\mathrm{H}_{5}$ : Effort expectancy is positively related to user's Perceived Satisfaction with using E- Services systems.

$\mathrm{H}_{6}$ : Communication is positively related to user's Perceived Benefits of using E- Services systems.

$\mathrm{H}_{7}$ : Knowledge Quality is positively related to user's Perceived Satisfaction with using E- Services systems.

$\mathrm{H}_{8}$ : Knowledge Quality is positively related to user's Perceived Benefits of using E- Services systems.

$\mathrm{H}_{9}$ : Information Quality is positively related to user's Perceived Satisfaction with using E- Services systems.

$\mathrm{H}_{10}$ : Information Quality is positively related to user's Perceived Benefits of using E- Services systems.

$\mathrm{H}_{11}$ : Job Motivation is positively related to user's continuance intention to use E-Services systems.

$\mathrm{H}_{12}$ : Social Influence is positively related to user's continuance intention to use E-Services systems.

$\mathrm{H}_{13}$ : Perceived Satisfaction is positively related to user's continuance intention to use E-Services systems.

$\mathrm{H}_{14}$ : Perceived Benefits of is positively related to user's continuance intention to use E-Services systems.

The moderating effect of Gender and EXPERINCE

$\mathrm{H}_{11 \mathrm{a}}$ : The gender moderates the relationship between Job Motivation and to user's continuance intention to use E-Services systems.

$\mathrm{H}_{13 \mathrm{a}}$ : The gender moderates the relationship between Perceived Satisfaction and user's continuance intention to use E-Services systems.

$\mathrm{H}_{11 \mathrm{~b}}$ : The employee EXPERINCE moderates the relationship between Job Motivation and user's continuance intention to use E-Services systems.

$\mathrm{H}_{14 \mathrm{~b}}$ : The employee EXPERINCE moderates the relationship between Perceived Benefits and user's continuance intention to use E-Services systems.

The below diagram presents the constructs model with the hypothesizes

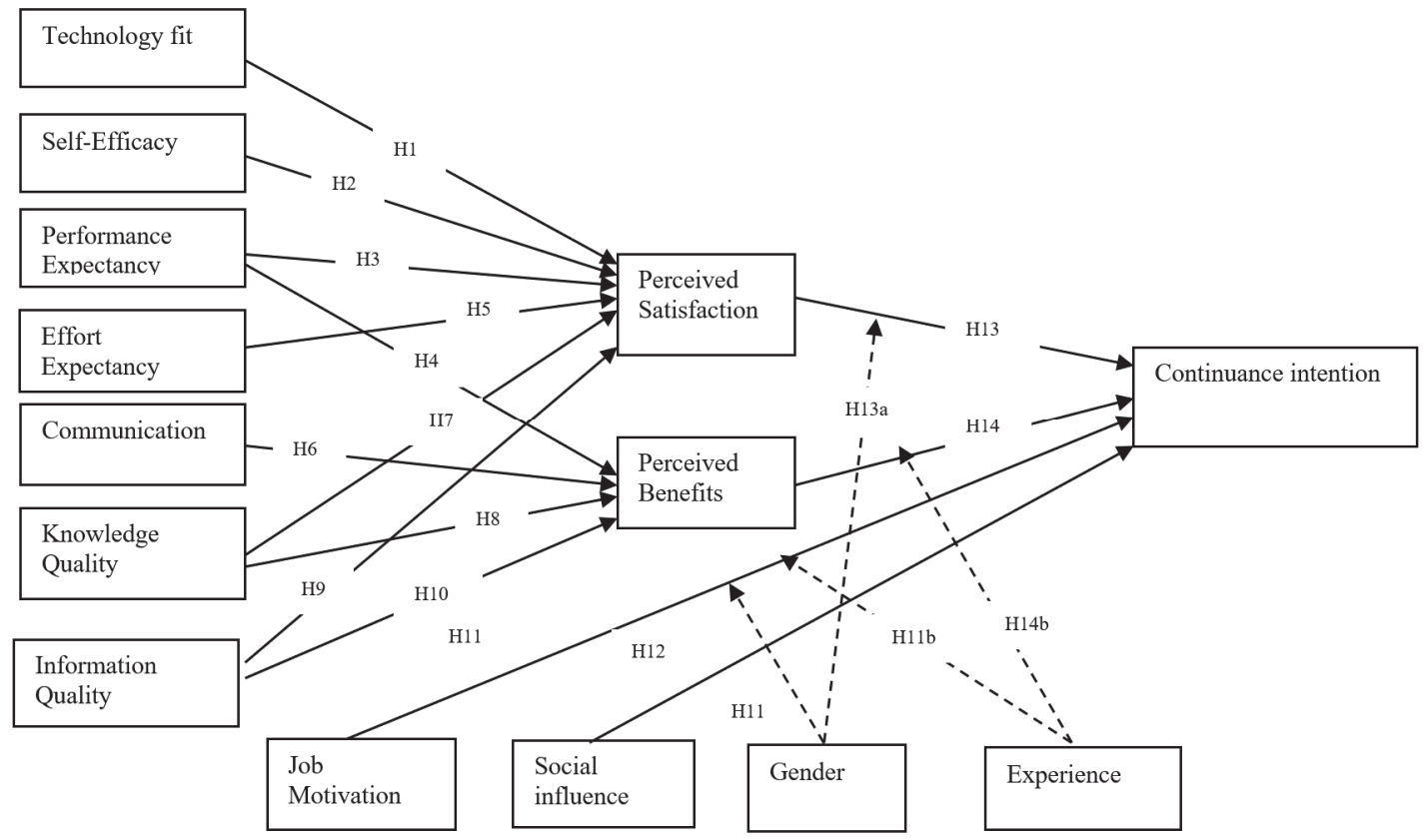

Fig. 1. Research Model

\section{Method}

\subsection{Sampling method and participants}

Fig. 2 illustrates the sample demographic characteristics. 


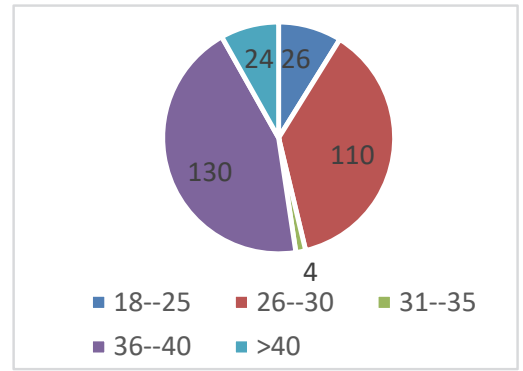

Age

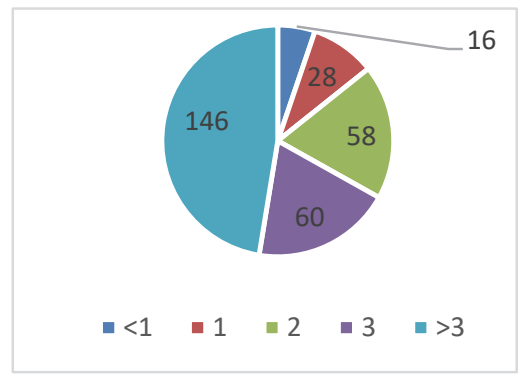

Years of Job experience

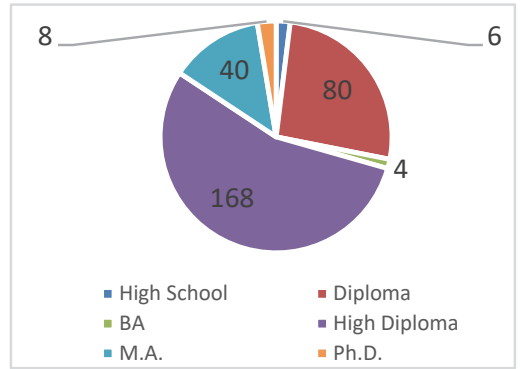

Educational background

Fig. 2. Personal characteristics of the participants

From the survey, we understand that $75.3 \%$ of the participants were female and $24.7 \%$ of them were male. Moreover, about $42.2 \%$ of the participants were in the age groups of $36-40,35.7 \%$ of them were in the age group of $26-30,8.4 \%$ of them were in the age group of $18-25$ and $7.8 \%$ of them aged more than 40 years old. The figure also shows details of the years of job experience and educational background.

\subsection{Reliability and validity of the measurement}

The survey questionnaire measurement tool included 47 items forming twelve latent variables. Cronbach's alpha was used for testing the internal consistency reliability of the scale. Cronbach's alphas are within the acceptable range. All constructs reported Cronbach's alpha value are greater than the critical value of 0.5 (between 0.77 and 0.89 ). Convergent validity was assessed by calculating composite reliability and the Average Variance Extracted (AVE) for each latent construct and indicated the sufficient reliability coefficients for all constructs.

The composite reliability (CR) values calculated according to the formula presented must be garter than 0.70

$$
\mathrm{CR}=\left[\left(\sum \boldsymbol{\theta}\right)^{2} /\left(\left(\sum \boldsymbol{\theta}\right)^{2}+\sum\left(\mathbf{1}-\boldsymbol{\theta}^{2}\right)\right)\right]
$$

where $\boldsymbol{\theta}=$ loading construct. Average variance is extracted analysis to establish discriminant validity. In an AVE analysis, we test to see whether the square root of AVE to each construct is much more than the correlation square between a pair construct. AVE measures the explained variance of the construct. When comparing AVE with the correlation coefficient we actually want to see whether the items of the construct explain more variance than do the items of the other constructs. AVE, which is a test of discriminant validity, is calculated as $\operatorname{AVE}=\left[\left(\sum \boldsymbol{\theta}\right)^{2} / \boldsymbol{N}\right]$ where $\theta$ is the loading of each measurement item on its corresponding construct. The rule says that the square root of the AVE of each construct should be much larger than the correlation of the specific construct with any of the other constructs. The value of AVE for each construct should be at least 0.50 (Fornell \& Larcker, 1981). AVE analysis as said before, the AVE values calculated according to the formula presented must be compared with the correlation coefficients of each construct with the other constructs. Therefore, first, it is necessary to obtain a matrix where we can see the correlation of each construct with the other constructs. Afterward, on the diagonal, we insert the AVE value in order to compare it with the other correlation coefficient. Table 1 shows results of the AVE analysis. It can easily be seen that the AVE values are above 0.5 and, moreover, are above the correlation coefficients for each construct. In addition, all constructs reported an AVE score exceeding 0.5.

Table 1

Reliability Statistics for the constructs

\begin{tabular}{|c|c|c|c|}
\hline Construct & Alpha Cronbach's & Composite Reliability & AVE \\
\hline Tec Fit & 0.87 & 0.90 & 0.82 \\
\hline $\mathrm{SE}$ & 0.77 & 0.85 & 0.78 \\
\hline $\mathrm{PE}$ & 0.89 & 0.84 & 0.42 \\
\hline EE & 0.74 & 0.81 & 0.60 \\
\hline Com & 0.85 & 0.87 & 0.66 \\
\hline KQ & 0.83 & 0.81 & 0.53 \\
\hline INFQ & 0.88 & 0.88 & 0.65 \\
\hline JOBM & 0.85 & 0.90 & 0.81 \\
\hline SI & 0.78 & 0.86 & 0.68 \\
\hline Psat & 0.78 & 0.79 & 0.55 \\
\hline PBEN (NetB) & 0.89 & 0.89 & 0.68 \\
\hline $\mathrm{CI}$ & 0.86 & 0.86 & 0.61 \\
\hline
\end{tabular}

We have computed Average Variance Extracted (AVE) by first squaring the construct loadings of each item, adding these scores for each construct (12 constructs in total) and then divide it by the number of items each construct had $(2,3,8,3,4,4$, 
$4,2,3,3,4$ and 4$)$. The results are $0.82,0.78,0.42,0.60,0.66,0.53,0.65,0.81,0.68,0.55,0.68$ and 0.61 . Discriminant validity was assessed by calculating the square root of the Average Variance Extracted (AVE) for each latent construct and comparing it with the other latent construct correlations squares. All constructs reported an AVE score exceeding 0.5. In addition, the square root of AVE for each construct is greater than all square of correlations of other constructs supporting the measurement discriminant validity (Table 1)

In this step, we find the correlation coefficients square and compare them with the square root of Average Variance Extracted from the contrast obtained. The square root of the extracted variance Extracted solves many of the problems that face some of the measures. Sometimes the correlation coefficient is higher than the average variance Extracted obtained, and here the researcher is confused with the criteria of the( Fornell-Larker). The only solution is the square root of the AVE. The square root of the Average Variance Extracted (AVE) for each construct was evaluated against its correlation square with the other constructs. Where the square root of AVE was greater than the construct's correlation square with other constructs, then Convergent validity was considered to be confirmed (Hair et al., 1998).

Table 2

\begin{tabular}{|c|c|c|c|c|c|c|c|c|c|c|c|c|}
\hline & Tec Fit & $\mathrm{SE}$ & $\mathrm{PE}$ & $\mathrm{EE}$ & Com & KQ & INFQ & JOBM & SI & PSat & PBEN NetB & CI \\
\hline Tec Fit & 0.91 & & & & & & & & & & & \\
\hline SE & 0.478 & 0.88 & & & & & & & & & & \\
\hline PE & 0.643 & 0.488 & 0.65 & & & & & & & & & \\
\hline $\mathrm{EE}$ & 0.527 & 0.536 & 0.542 & 0.77 & & & & & & & & \\
\hline Com & 0.476 & 0.424 & 0.594 & 0.496 & 0.81 & & & & & & & \\
\hline KQ & 0.361 & 0.272 & 0.503 & 0.356 & 0.571 & 0.73 & & & & & & \\
\hline INFQ & 0.545 & 0.464 & 0.581 & 0.476 & 0.623 & 0.610 & 0.81 & & & & & \\
\hline JOBM & 0.433 & 0.319 & 0.430 & 0.383 & 0.358 & 0.446 & 0.506 & 0.90 & & & & \\
\hline SI & 0.179 & 0.359 & 0.287 & 0.294 & 0.408 & 0.245 & 0.346 & 0.177 & 0.82 & & & \\
\hline PSat & 0.409 & 0.407 & 0.465 & 0.474 & 0.585 & 0.509 & 0.486 & 0.425 & 0.374 & 0.74 & & \\
\hline PBEN NetB & 0.602 & 0.411 & 0.585 & 0.534 & 0.645 & 0.512 & 0.610 & 0.474 & 0.237 & 0.548 & 0.82 & .538 \\
\hline $\mathrm{CI}$ & 0.494 & 0.339 & 0.502 & 0.500 & 0.483 & 0.484 & 0.565 & 0.614 & 0.263 & 0.517 & 0.538 & 0.78 \\
\hline
\end{tabular}

Discriminant Validity:

- Inter-construct correlation matrix with square root the AVE on the Diagonal.

- Discriminant Validity: the square root of the AVE on the Diagonal is greater than Inter-construct correlations square.

- Inter-construct correlations are less than 0.90 which means they do not have any multicollinearity.

- The square root of Average Variance extracted $>$ (correlation) 2, hence discriminant validity is established.

- We understand that for Discriminant Validity, the square root of the Average Variance Extracted (AVE) value of a construct should be higher than correlation square of that variable with other constructs.

- We have computed Average Variance Extracted (AVE) by first squaring the construct loadings of each item, adding these scores for each construct ( 12 constructs in total) and then divide it by the number of items each construct had $(2,3,8,3,4,4,4,2,3,3,4$ and 4$)$. The results are $0.82,0.78,0.42,0.60,0.66,0.53,0.65,0.81,0.68,0.55,0.68$ and 0.61 .

- The above AVE Values are calculated and compared with the correlation square OR and we have to square root these values $(\sqrt{0.82}=0.91 ; \sqrt{0.78}=0.88 ; \sqrt{0.42}=0.65 ; \sqrt{0.60}=0.77 ; \sqrt{0.66}=0.81 ; \sqrt{0.53}=0.73 ; \sqrt{0.65}=$ $0.81 ; \sqrt{0.81}=0.90 ; \sqrt{0.68}=0.82 ; \sqrt{0.55}=0.74 ; \sqrt{0.68}=0.82 ;$ and $\sqrt{0.61}=0.78$ then we compare the results with the correlation square.

- If square root Average Variance extracted $>(\text { correlation })^{2}$, hence discriminant validity is established.

- We see from above table the Average Variance extracted is greater than all the correlation square in the matrix, and then discriminant validity established.

\section{The results}

Structural Equation Modelling (SEM) technique was used to test the model hypotheses to investigate the relationships between variables. The Goodness of fit measures (GOF) was assessed using the confirmatory factor analysis. The model reported and an Average R-squared (ARS) is equal to $(0.92)$ with $\mathrm{P}=0.000$. The results of testing the research model are presented in Fig. 3 , and summarized in Table 3 


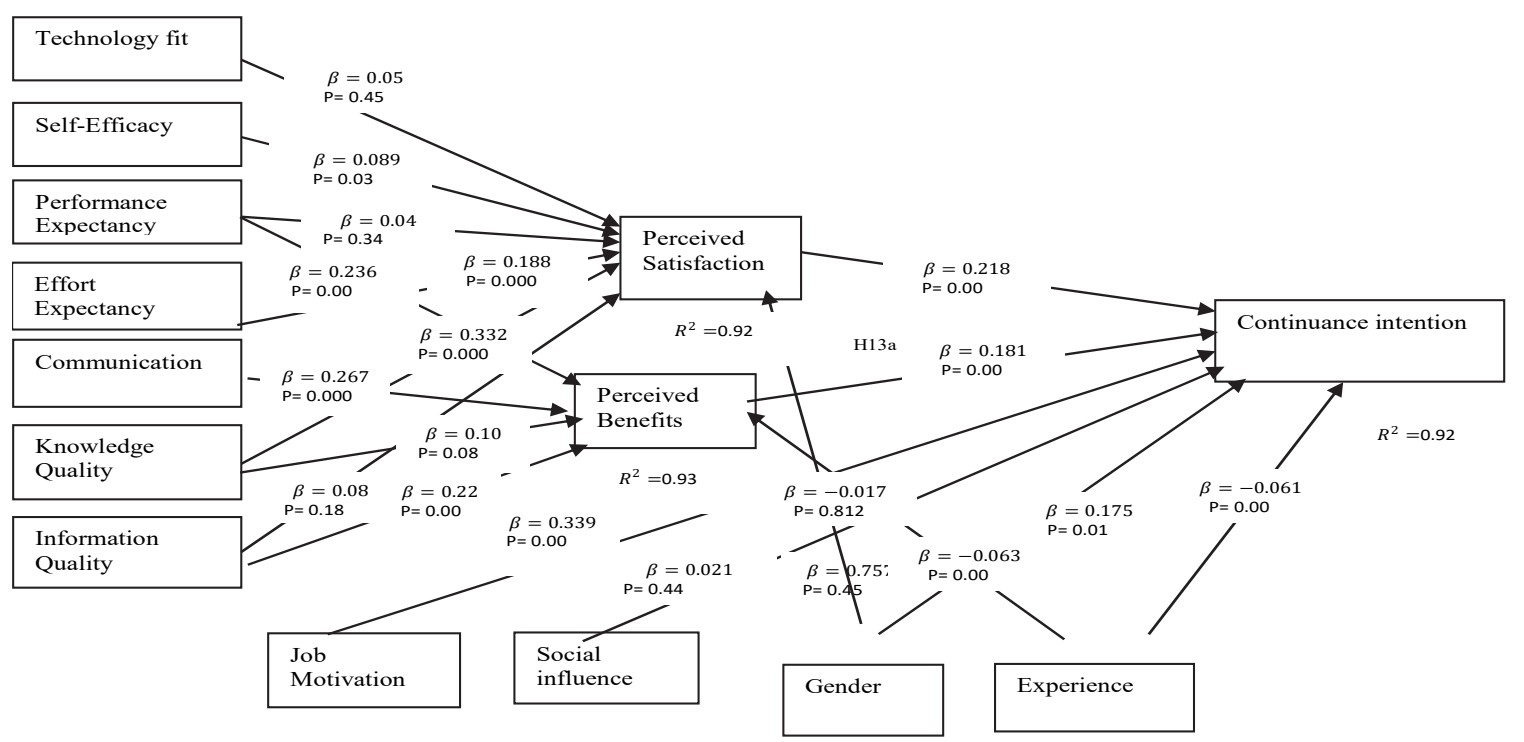

Fig. 2. Model with analysis result

Table 3

Model Result

\begin{tabular}{|c|c|c|c|c|c|}
\hline Hypothesis & $\mathrm{B}$ & S.E. & C.R. & P-Value & Conclusion \\
\hline $\begin{array}{l}\text { H1: technology fit is positively related to user's Perceived Satisfaction with } \\
\text { using Computerized Systems in Administration }\end{array}$ & 0.050 & 0.066 & 0.757 & 0.45 & Not Significant \\
\hline $\begin{array}{l}\text { H2: Self-Efficacy is positively related to user's Perceived Satisfaction with } \\
\text { using Computerized Systems in Administration. }\end{array}$ & 0.089 & 0.041 & 2.178 & 0.03 & Significant \\
\hline $\begin{array}{l}\text { H3: Performance expectancy is positively related to user's Perceived Satis- } \\
\text { faction with using Computerized Systems in Administration }\end{array}$ & 0.074 & 0.076 & 0.963 & 0.34 & Not Significant \\
\hline $\begin{array}{l}\text { H4: Performance expectancy is positively related to user's Perceived Bene- } \\
\text { fits of using Computerized Systems in Administration. }\end{array}$ & 0.236 & 0.059 & 4.004 & $* * *$ & Significant \\
\hline $\begin{array}{l}\text { H5: Effort expectancy is positively related to user's Perceived Satisfaction } \\
\text { with using Computerized Systems in Administration }\end{array}$ & 0.188 & 0.056 & 3.369 & $* * *$ & Significant \\
\hline $\begin{array}{l}\text { H6: Communication is positively related to user's Perceived Benefits of us- } \\
\text { ing Computerized Systems in Administration. }\end{array}$ & 0.267 & 0.043 & 6.175 & $* * *$ & Significant \\
\hline $\begin{array}{l}\text { H7: Knowledge Quality is positively related to user's Perceived Satisfaction } \\
\text { with using Computerized Systems in Administration. }\end{array}$ & 0.332 & 0.064 & 5.199 & $* * *$ & Significant \\
\hline $\begin{array}{l}\text { H8: Knowledge Quality is positively related to user's Perceived Benefits of } \\
\text { using Computerized Systems in Administration. }\end{array}$ & 0.100 & 0.057 & 1.748 & 0.08 & Not Significant \\
\hline $\begin{array}{l}\text { H9: Information Quality is positively related to user's Perceived Satisfaction } \\
\text { with using Computerized Systems in Administration. }\end{array}$ & 0.080 & 0.060 & 1.339 & 0.18 & Not Significant \\
\hline $\begin{array}{l}\text { H10: Information Quality is positively related to user's Perceived Benefits } \\
\text { with using Computerized Systems in Administration }\end{array}$ & 0.223 & 0.051 & 4.406 & $* * *$ & Significant \\
\hline $\begin{array}{l}\text { H11: job Motivation is positively related to user's continuance intention to } \\
\text { use Computerized Systems in Administration }\end{array}$ & 0.339 & 0.035 & 9.659 & $* * *$ & Significant \\
\hline $\begin{array}{l}\text { H12: Social Influence is positively related to user's continuance intention to } \\
\text { use Computerized Systems in Administration. }\end{array}$ & 0.021 & 0.027 & 0.772 & 0.44 & Not Significant \\
\hline $\begin{array}{l}\text { H13 Perceived Satisfaction is positively related to user's continuance inten- } \\
\text { tion to use Computerized Systems in Administration. }\end{array}$ & 0.218 & 0.045 & 4.855 & $* * *$ & Significant \\
\hline $\begin{array}{l}\text { H14: Perceived Benefits is positively related to user's continuance intention } \\
\text { to use Computerized Systems in Administration. }\end{array}$ & 0.181 & 0.046 & 3.941 & $* * *$ & Significant \\
\hline $\begin{array}{l}\text { H15: The gender is negatively related to user's Perceived Satisfaction to use } \\
\text { Computerized Systems in Administration. }\end{array}$ & -0.017 & 0.073 & -0.238 & 0.81 & Not Significant \\
\hline $\begin{array}{l}\text { H16: The gender is positively related to user's continuance intention to use } \\
\text { Computerized Systems in Administration }\end{array}$ & 0.175 & 0.071 & 2.479 & 0.01 & Significant \\
\hline $\begin{array}{l}\text { H17: The Experience is negatively related to user's Perceived Benefits to use } \\
\text { Computerized Systems in Administration. }\end{array}$ & -0.063 & 0.021 & -2.954 & $* * *$ & Significant \\
\hline $\begin{array}{l}\text { H18: The Experience is negatively related to user's continuance intention to } \\
\text { use Computerized Systems in Administration }\end{array}$ & -0.061 & 0.023 & -2.692 & 0.01 & Significant \\
\hline
\end{tabular}

\section{Results and discussion}

Based on the SEM analysis and using SPSS AMOS version 25, fourteen out of eighteen research hypotheses were significant leaving six hypotheses unsupported. The influence of each of Effort expectancy, Self-Efficacy, and Knowledge Quality, on 
user's Perceived Satisfaction with using E-Services, was Significant $(\mathrm{p}<0.01)$. Performance expectancy, Communication and Information Quality on user's Perceived Benefits with using E-Services were Significant $(\mathrm{P}<0.01)$. Job Motivation, Perceived Satisfaction, the gender, and Perceived Benefits of user's continuance intention with using E-Services were Significant at the $\mathrm{p}<0.01$. The Experience was negatively related to user's Perceived Benefits to use E-Services. The Experience was negatively related to user's continuance intention to use E-Services. The others six research hypotheses were Not Significant according to the results.

Technology fit was positively related to user's Perceived Satisfaction with using E-Services, Performance expectancy was positively related to user's Perceived Satisfaction with using E-Services, Knowledge Quality is positively related to user's Perceived Benefits of using E-Services, Information Quality is positively related to user's Perceived Satisfaction with using E-Services, Social Influence is positively related to user's continuance intention to use E-Services, the gender was negatively related to user's Perceived Satisfaction to use E-Services.

\section{Conclusion and future work}

This paper aimed to identify the acceptance of using e-services by nonacademic staff at universities. The technology acceptance model (TAM) was used to develop a model. The model consisted of multiple constructs that reflect the opinion of nonacademic in e-service to intention to use. In addition, the model was validated and tested. The outputs of this research could be used by ICT department to increase the quality and flexibility of eservices. As result of this research, technology fit was positively related to user's Perceived Satisfaction with using e-services.

As future works, to enhance the model accuracy, some variables need to be added related to job environments since the job environment has direct effects on employees' performance.

\section{Acknowledgement}

This project was supported by the Deanship of Scientific Research at Prince Sattam Bin Abdulaziz University under the research project \# 2017/02/7654

\section{References}

Ali, H. (2019). Measurement of e-services quality: an empirical study of University of Bahrain. Education and Information Technologies, 24(3), 1907-1924.

Chiu, C. M., \& Wang, E. T. (2008). Understanding Web-based learning continuance intention: The role of subjective task value. Information \& Management, 45(3), 194-201.

Delone, W. H., \& McLean, E. R. (2003). The DeLone and McLean model of information systems success: a ten-year update. Journal of management information systems, 19(4), 9-30.

Dishaw, M. T., \& Strong, D. M. (1999). Extending the technology acceptance model with task-technology fit constructs. Information \& management, 36(1), 9-21.

Goodhue, D. L., \& Thompson, R. L. (1995). Task-technology fit and individual performance. MIS quarterly, 213-236.

Hair, J. F., Black, W. C., Babin, B. J., Anderson, R. E., \& Tatham, R. L. (1998). Multivariate data analysis (Vol. 5, No. 3, pp. 207-219). Upper Saddle River, NJ: Prentice hall.

Lin, W. S., \& Wang, C. H. (2012). Antecedences to continued intentions of adopting e-learning system in blended learning instruction: A contingency framework based on models of information system success and task-technology fit. Computers \& Education, 58(1), 88-99.

Naicker, S., \& Singh, A. (2019, March). Developing a framework towards improving business analysis of integrated public e-service systems. In 2019 Conference on Information Communications Technology and Society (ICTAS) (pp. 1-6). IEEE.

Persico, D., Manca, S., \& Pozzi, F. (2014). Adapting the Technology Acceptance Model to evaluate the innovative potential of e-learning systems. Computers in Human Behavior, 30, 614-622.

Taherdoost, H. (2018). Development of an adoption model to assess user acceptance of e-service technology: EService Technology Acceptance Model. Behaviour \& Information Technology, 37(2), 173-197.

Venkatesh, V., Morris, M. G., Davis, G. B., \& Davis, F. D. (2003). User acceptance of information technology: Toward a unified view. MIS quarterly, 27(3), 425-478.

Wang, Y. S., Wang, H. Y., \& Shee, D. Y. (2007). Measuring e-learning systems success in an organizational context: Scale development and validation. Computers in Human Behavior, 23(4), 1792-1808. 
(C) 2020 by the authors; licensee Growing Science, Canada. This is an open access article distributed under the terms and conditions of the Creative Commons Attribution (CC-BY) license (http://creativecommons.org/licenses/by/4.0/). 